University of Nebraska - Lincoln

DigitalCommons@University of Nebraska - Lincoln

3-1932

ON THE DATING OF THE ENGLISH AND SCOTTISH BALLADS

Louise Pound

Follow this and additional works at: https://digitalcommons.unl.edu/englishfacpubs

Part of the Comparative Literature Commons, English Language and Literature Commons, Modern Literature Commons, and the Reading and Language Commons

This Article is brought to you for free and open access by the English, Department of at DigitalCommons@University of Nebraska - Lincoln. It has been accepted for inclusion in Faculty Publications -Department of English by an authorized administrator of DigitalCommons@University of Nebraska - Lincoln. 
PMLA, Vol. 47, No. 1 (Mar., 1932), pp.

$10-16$

II

\section{ON THE DATING OF THE ENGLISH AND SCOTTISH BALLADS}

$\mathrm{T}$ HE practice has established itself among literary historians and anthologists of associating the English and Scottish ballads primarily with the fifteenth century, sometimes with the fourteenth and fifteenth centuries. One of the best and most popular of the histories of English literature now used in schools and colleges states in its revised editions: "These ballads appear to have flourished luxuriantly among the folk in the fourteenth and fifteenth centuries, after which their composition ceased. Over three hundred of them, in 1,300 versions, have survived, and have been collected and printed." English Literature by M. Emile Legouis, the most ambitious among recent histories of our literature, remarks of the ballads: "They cannot all be claimed for the fifteenth century, for poems of this sort must have had an earlier beginning and certainly were produced until a later time, but the impulse to make them seems to have been particularly active in this century, to which, moreover, the oldest extant specimens belong." recent excellent poetical anthology has: "Ballad is the name applied to a simple form of narrative poetry which in England and Scotland flourished between the fourteenth and sixteenth centuries." 3 Statements like these leave with readers the definite impression that the fifteenth century was the heyday of ballad production, and that the bulk of the three hundred ballads in Professor Child's collection emerged from this century, or from an even earlier period.

An examination of the standard historical anthologies used in schools and colleges leaves the same impression with readers. In one of the most recent," the exhibit of English ballads-including "Edward" and "Sir Patrick Spens"-comes directly after Chaucer. The display precedes, not follows, lyrics like the well-known "Cuckoo Song" of the thirteenth century, "Springtime," "Alysoun," "A Plea for Pity," "Blow, Northern Wind," and even the Quem Quaeritis trope. Another, ${ }^{5}$ under the heading "Chaucer to the Renaissance," enters "Captain Car," or "Edom O'Gordon," "Lord Randal," "The Wife of Usher's Well," and "Bonny Barbara

${ }^{1}$ Moody and Lovett, History of English Literature, 1902, 1918, etc., page 67.

${ }^{2}$ A History of English Literature: The Middle Ages and the Renaissance. Translated by H. D Irvine. 1926.

${ }^{3}$ Jacob Zeitlin and Clarissa Rinaker. Types of Poetry, 1926.

4 James Dow McCallum, The Beginnings to 1500, 1929. Scribner's English Literature series.

${ }^{5}$ J. W. Cunliffe, J. F. A. Pyre, Karl Young, Century Readings in English Literature, 1929. 
Allan." Another ${ }^{6}$ has "Edward," "Sir Patrick Spens," "The Wife of Usher's Well," "The Two Corbies," and "Mary Hamilton," under "The Later Middle Ages." Another" has, under "The End of the Middle Ages," "Edward," "Sir Patrick Spens," "The Wife of Usher's Well," "Bonnie George Campbell." Another, ${ }^{8}$ one of the most recent, enters under the heading "The Age of Chaucer," "Edward," "Sir Patrick Spens," "The Wife of Usher's Well," "Bonny Barbara Allan," and "Johnny Armstrong." These precede, as in the anthology first cited, the thirteenth-century "Cuckoo Song," and the early lyrics, "Springtime," "Alysoun," "A Plea for Pity," and "Blow, Northern Wind." Another, ${ }^{9}$ which has on the whole careful chronological arrangement, supplies the heading "Ballads of Uncertain Date," but enters among them "The Nut-Brown Maid," and "Helen of Kirconnell," the first of which is, as pointed out long ago, a verse debate, a bit of special pleading, while the second is a pure lyric. Both were once accounted ballads but both were excluded from his collection by Professor Child. Professor Reed Smith, in a recent anthology of South Carolina ballads" ${ }^{10}$ writes of "Five Hundred Years of "The Maid Freed from the Gallows'," remarking that it was "composed before Chaucer's pilgrimage," although our earliest text of it comes from the Percy Papers of the eighteenth century and we are ignorant of its antecedent history. There is not a scrap of evidence to connect it with the days before Chaucer's pilgrimage.

Accounts of ballads or displays of ballad texts are often accompanied by statements such as "ballads have no dates," "it is impossible to assign dates to ballads," or "the dates of ballads are unknown"; and this explains, no doubt, the far from careful way in which the texts are placed chronologically. The effect, however, on the users of anthologies is to lead them to believe that the body of the Child ballads, or at least, the illustrative texts entered for the student to read, date from before the Renaissance.

${ }^{6}$ Lieder, Lovett, and Root, British Poetry and Prose, 1928.

"Snyder and Martin, A Book of English Literature, 1916. "The End of the Middle Ages" is also the heading under which ballads are placed in J. M. Manly's English Poetry 1170-1892, 1907.

8 T. P. Cross and C. T. Goode, Readings in the Literature of England, 1927.

9 H. S. Pancoast, English Verse and Prose, 1915. "Middle English Writers" is the heading under which ballads are grouped in The Modern Student's Book of English Literature, by H. M. Ayres, W. D. Howe, and F. M. Padelford, 1924. G. H. Gerould in his Old English and Medieval Literature (1929) devotes more than a hundred pages to illustrations of fifteenth-century literature. All but about twenty of these pages are given over to a miscellany of Child ballads, among them "Mary Hamilton," Percy's literary text of "Edward," etc.

${ }^{10}$ South Carolina Ballads. 1928. 
Professor Ewald Fluegel, in an article in Anglia as far back as 1899,11 made a valuable survey of the dating of the ballad texts. He found that one of the Child texts comes from the thirteenth century, none from the fourteenth, very few from the fifteenth (only a few clerical and greenwood pieces antedate 1500), and ten or fewer may come from the sixteenth. Thus not more than fifteen or twenty, at the most liberal estimate, of the texts coming down to us antedate 1600 . The number usually given is eleven..$^{12}$ The rest of the hundreds of the Child texts come from the seventeenth, eighteenth, and nineteenth centuries. The date of the recovery of ballad texts is not the same thing, of course, as establishing the dates of their origin. A ballad may have been composed much earlier than the earliest text of it that happened to be preserved. Naturally, too, most texts would reach us from later centuries, since conscious efforts to find and to preserve ballads came late. But, at least, Professor Fluegel's survey affords no evidence for the pre-Renaissance period as that of their greatest popularity and production. It does not justify sentences like "After the fourteenth and fifteenth centuries their composition ceased." Other lyric matter, both popular and secular, has come down to us in abundance from before the Renaissance, but, curiously enough, not ballads.

Professor Frank Bryant in his Harvard dissertation on the history of ballads, ${ }^{13}$ reached the conclusion: "If the Child type was at all common [in the reign of Elizabeth] the almost universal silence about it is as strange as it was undeserved. . . . My own conclusion," he adds, "- oft arrived at-is, therefore, that the Child ballad was not much current in Southern England." Professor Bryant reached this opinion after a careful survey of the history of English and Scottish ballad material, and I have always felt inclined to agree with him.

Is it not time that we stopped repeating so mechanically and unqualifiedly that "ballads have no dates"? Though we may not be able to date accurately a large number of them, yet each had its date if we could find it. Occasionally the general period from which a ballad emerged can be determined by the nature or content-the subject-matter or story-of the oldest text; or by the slant of the composer in handling his narrative; or by the ballad style in which he composed. To illustrate, among the Robin Hood ballads, those in which England is reflected as yet Catholic must have come from the period before the Protestantizing of England. Those in which Robin Hood is burlesqued or disparaged must have been

11 Anglia, xxr, Neue Folge, Ix, 312-358.

12 Cf., for instance: "Only some eleven of the ballads are preserved in documents older than the seventeenth century." Century Readings in English Literature, page 105.

${ }^{13}$ A History of British Balladry, 1913, page 192. 
late of composition, when the tradition was in its decay. The ballads of "The Hunting of the Cheviot" and "The Battle of Otterburne" cannot have preceded the events with which they profess to deal, although the composition of them might come from as late as the early sixteenth century, much as our best-known poem of John Brown comes, not from the date of his activities but from our own decade. The allegorical "Rose of England," reflects unmistakably the period of the civil Wars of the Roses. The terminus a quo, at least, can often be established with no uncertainty at all. Ballads cannot be earlier than the events they celebrate, where they are not obviously adaptations, as certain American narratives, of pieces already in existence.

I wish here to protest, in general, against the customary sweeping references by literary historians and critics to "the ballads," accompanied by no effort to place them with whatever chronological exactness may be possible. There are many layers of the Child ballads. They come from different periods and different regions, and they are composed in different styles. When we group them historically we ought to try to do so with discrimination, selecting as carefully as we can those that may best be associated with the historical period that we have in mind. The association may be suggested by the events treated, or the character of the narrative, or by the style, or by the date of recovery of the text. But certainly one of these considerations should be taken into account when texts are presented to illustrate certain periods. The Child ballads include many classes: sacred legends and classical stories, riddle ballads, and wit contests, ballads of the greenwood, (these are earlier types), chronicle ballads, Border ballads, ballads of the dying or dead, nautical ballads, ballads of domestic tragedy, love stories, romances, ballads of the supernatural, humorous ballads. They bear plain traces of emerging from different periods and of conforming to changing tastes. It is as unscientific to speak sweepingly of "the ballads" as it is to speak of the body of English sonnets, from four centuries, as "the sonnets," or to speak of "the odes," "the hymns," or "the elegies," as though they were the homogeneous products of one or two periods.

Let us return to the matter of the ballad groupings made by literary anthologists. The events chronicled in "Johnny Armstrong" took place, according to Professor Child's investigations, in 1530. The ballad might have been composed some time after that date. It could not have been composed before it. Why allow it, then, to appear in the Age of Chaucer? The burning of the house of Towie by Captain Car ("Edom O'Gordon") occurred in 1571. Why, then, place the ballad telling of this event before 1500 , as though antedating the Renaissance? "Mary Hamilton" belongs, in the events narrated, in the reign of Mary Stuart. Why place it under 
"The Later Middle Ages"? We first hear of "Barbara Allan" as the Scotch song of a London actress, heard by the diarist Samuel Pepys. It is about what it ought to be for a stage song of the seventeenth century. A hundred years later Goldsmith heard it sung by a dairymaid, the natural fate of a London success of the preceding century. Yet this song also has been placed in the "Age of Chaucer." Sir Walter Scott's striking text of "The Wife of Usher's Well" is a favorite among ballads placed in early periods by anthologists. His is a rather suspicious version, probably touched up by him. The texts of this ballad are yet to be studied; but those that are not Scott's, (especially the American texts, which often retain earlier features of the Child ballads than do those from the Old World) are so different from his as to bring his into question. In any case, the ballad gives better testimony concerning late eighteenth-century Scottish folk-song than it does concerning that of Chaucer's time. "The Two Corbies" is another of Scott's texts, and sounds like it. If this song is to be placed "Before the Renaissance," it would be wiser to select the earlier seventeenth-century text of it from Melismata (1611), "The Three Ravens," than to go to Scott's Minstrelsy of 1802. Much the same protest may be made against "Edward," placed early by a majority of anthologists, doubtless because of the formerly-held theory that "situation songs" represent a very early type. Percy's version of "Edward" is a quite isolated one, composed in literary Scots of the eighteenth century. Professor Archer Taylor has pointed out ${ }^{14}$ that the many other texts of this song are not debased versions of Percy's texts. Percy's may be the manipulated text, while the other versions represent an older form of the story. "Edward" no more belongs properly in the Age of Chaucer than does "Lord Randal," for which Sir Walter Scott's is one of the older English texts. We have our first knowledge of this song as belonging to the repertory of an Italian professional singer in Verona in the seventeenth century. That it existed in England at Chaucer's time is extremely unlikely. Of "Sir Patrick Spens" we know nothing before Percy's Reliques. "Bonnie George Campbell" is almost a pure lyric, hardly a ballad at all, and it cannot be traced back of the eighteenth century.

In general, an impressive number of the Child ballads can be dated by the events they describe. To illustrate, the sea fight narrated in "Sir Andrew Barton" took place in 1511. The exploit celebrated in "Jock O the Side" took place about 1550, and that in "Archie O Cawfield" about 1579. That referred to in "Willie Macintosh" came in 1592, and so did the events in the "Bonnie Earl of Murray" and "The Laird O Logie." "The Lads O Wamphray" tells of a skirmish that took place in 1593.

14 "'The Texts of 'Edward' in Percy's 'Reliques' and Motherwell's 'Minstrelsy'." $M L N$, April, 1930. 
The exploit told in "Kinmont Willie" took place in 1596. The murder in "The Laird of Wariston" took place in 1600. Lord Maxfield of "Lord Maxfield's Last Goodnight" was executed in 1613. The pillaging of the "Bonny House of Airlie" was in 1640. Johnny Faa of "The Gypsy Laddie" belonged in the first half of the century; he was executed in 1624 . The death of "Bessie Bell and Mary Gray" may be referred to the plague of 1645 , etc. ${ }^{15}$

It is natural, I think, that the fifteenth century, despite its meagreness of ballad production, should be given chief emphasis in literary histories and anthologies. It is more convenient to give them space there than in the crowded following century, the sixteenth, or to let them follow Percy's Reliques in the yet more crowded eighteenth century. Another reason for our favoring the fifteenth century is that we like to think of "the ballads" vaguely as "old," and the fifteenth century affords a last chance to enter them as mediæval. The tradition started of presenting them here; it has never been given up, nor its validity questioned. Probably it need not be given up. Ballads may be treated with a degree of appropriateness in the fifteenth century as a time when the type was definitely emerging. The century should not have too great emphasis, however nor should students be led to believe that they flourished luxuriantly then, and that soon after their composition ceased. Further, the texts cited in illustration should be confined to those that, with some probability, may be cited as late mediæval. The canvassings of Fluegel and Bryant suggest the throwing forward of the date of production of the Child ballads, in the mass, until later centuries; and this shift forward is valid, I think. Their heyday came after, not before, the Renaissance.

The typical ballads that most writers on the subject recall, when admiring the spirited quality of ballads, their lyrical appeal, and the characteristics of their style, are those of Scotland, of the seventeenth and eighteenth centuries, the selected texts touched up by Sir Walter Scott,

\footnotetext{
${ }^{15}$ I have made no exhaustive examination of the Child ballads for the dates of the events they narrate, where these can be determined; but the following are additional examples of ballads dealing, according to Professor Child, with events that occurred in the sixteenth, seventeenth, and eighteenth centuries: No. 168, "Flodden Field," 170, "The Death of Queen Jane," 171, "Thomas Cromwell," 172, "Musselburgh Field," 174, "Earl Bothwell," 175, "The Rising in the North," 176, "Northumberland Betrayed by Douglas," 177, "The Earl of Westmoreland," 179, "Rookhope Ryde," 180, "King James and Brown," 196, "The Fire of Frendraught," 197, "James Grant," 198, "Bonny John Seton," 202, "The Battle of Philiphaugh," 203, "The Baron of Brackley," 204, "Jamie Douglas," 205, "Loudon Hill," 206, "Bothwell Bridge," 207, "Lord Delamere," 208, "Lord Derwentwater," 209, "Geordie," 225, "Rob Roy," 229, "Earl Crawford," 230, "The Slaughter of the Laird of Mellerstain," 231, "The Earl of Erroll," 232, "Richie Story," 233, "Andrew Lammie," 236, "The Laird o Drum," 287, "Captain Ward and the Rainbow.".
} 
or those printed by the great Scottish collectors who specialized in the best texts that they could find. It is partly, too, because of this specialization on the part of the nineteenth-century collectors, and because of our formulation of our ideas of the ballads from the attractive Scotch ballad style, that we have so exalted an idea of the poetical quality of English folk-song as a whole. Weak and crude texts existed, of course, alongside the poetical ones, but no one preserved them. The collectors of the twentieth century preserve whatever they find, good and bad. The great collectors of nineteenth-century Scotland preserved the best they could find, and thought the rest negligible.

The purpose of this brief paper has been to make a plea, first, against overemphasis on the fifteenth century as the heyday of ballad popularity and production; second, against too sweeping assertion that "ballads have no dates"; for it is possible to date, approximately, a surprising number of them; third, against too sweeping references to "the ballads," as though no discriminations need be made concerning them; and, fourth, against too great carelessness of chronological considerations in the selection of texts for period-placement in anthologies.

University of Nebraska

Louise Pound 